The Free Internet Journal

for Organic Chemistry
Account

Arkivoc 2020, part ii, 123-133

\title{
A combined EPR spectroscopy and DFT-based structural interpretation of the antitumor properties of oxindolimine-copper(II) complexes
}

\author{
Rodrigo B. Fazzi, Raphael E. Ferraz de Paiva, and Ana M. Da Costa Ferreira* \\ Departamento de Química Fundamental, Instituto de Química, Universidade de São Paulo, \\ Av. Prof. Lineu Prestes 748, 05508-000 São Paulo, SP, Brazil \\ Email: amdcferr@iq.usp.br
}

Dedicated to Professor José Manuel Riveros in the occasion of his 80th birthday

Received 01-20-2020

Accepted 04-12-2020

Published on line 04-23-2020

\section{Abstract}

Some oxindolimine-copper(II) complexes have been designed and investigated as potential antitumor compounds, inhibiting significantly diverse tumor cell growth, and having as main targets DNA, and crucial proteins, as topoisomerases and kinases. Binding efficiently to DNA, they induce apoptosis by an oxidative mechanism. As lipophilic cations they also act as decoupling agents in the mitochondria, depleting the membrane potential. All those properties are direct consequences of their structural characteristics and geometry around the coordination center. By using a combination of DFT calculations and structural EPR spectroscopic data, we managed to rationalize experimental data, and uncover key factors affecting their reactivity.
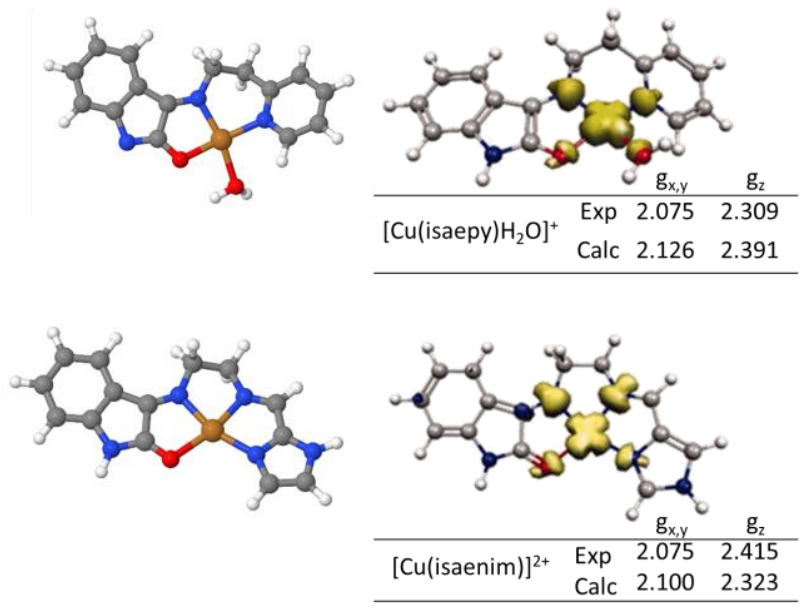

$\mathrm{Cu}(\mathrm{II})$ complexes with imine ligands

Mulliken Spin Density Isosurfaces (BPW91-60/TZVP)

Keywords: Oxindolimines; copper complexes; EPR spectroscopy; apoptosis; antitumor activity 


\section{Table of Contents}

\section{Introduction}

2. DFT methods as a theoretical support for EPR spectroscopy

3. EPR-based structural data and antiproliferative activities of copper(II) compounds

4. Interactions of oxindolimine-copper(II) complexes with biomolecules

5. Conclusions

Acknowledgements

References

\section{Introduction}

The computational study of metallodrugs with pharmacological or medicinal uses has received especial attention in recent decades, since the biological activity of such compounds can be simulated and explained by readily accessible and widespread methodologies, thereby focusing the development of novel therapeutic drugs. Additionally, structure-based prediction of biological activities of metallodrugs can often be achieved based on these computational analyses, by making a direct correlation with affinity and binding modes with specific biomolecular targets. ${ }^{1,2}$ Rationalizing the factors affecting the reactivity of these compounds in biological media is a challenge that demands much effort from multidisciplinary teams, with chemical computation providing a strong support for spectroscopic and biochemical assays. ${ }^{1-4}$

SAR (structure-activity relationship) studies are ubiquitous in the literature, focusing potential compounds with pharmaceutical interest. Many lead compounds are optimized and expanded on by this methodology, before being synthesized and experimentally tested, minimizing the cost and time required for the development of new drugs. A recent example is the comparison of cyclic imides with remarkable activity against the parasite Trypanosoma cruzi. A study based on the binding of this class of compound to cruzain, a cystein protease predominant in the parasites, allowed the development of reversible competitive inhibitors of the enzyme. Docking calculations to the protein catalytic site demonstrated that a bulky hydrophobic side chain is essential for a strong ligand-pocket interaction. Experimental results showed that the incorporation of different substituents in the imide moiety modulates the inhibitory activity. ${ }^{5}$

The field of copper(II)-based metallodrugs is thriving within the bioinorganic community, ${ }^{6-9}$ and many investigations include experimental data supported by magnetic spectroscopy and theoretical simulations. ${ }^{10}$ As a $\mathrm{d}^{9}$ metal center, copper(II) is paramagnetic, and therefore EPR spectroscopy appears as a powerful technique providing structural information that NMR is often unable to offer for this class of compounds. One often-used approach to provide theoretical support for the EPR spectroscopic data is the simulation of the spectra based on EPR packages such as Easyspin, ${ }^{11}$ Sinfonia (Bruker) and others. These programs make use of the EPR fundamental equations (Plank equation, g-factor equation) and wave functions to simulate the experimental spectrum, also providing accurate measurements of the g-factor and other EPR parameters. Another possible approach is based on spin-unrestricted density functional theory (DFT) calculations, which can accurately describe spectroscopic and spin density-based properties of paramagnetic systems. It is an excellent approach in order to determine the structure of the complexes beside the distribution of the spin density. ${ }^{12,13}$ DFT has also been successfully used for supporting or predicting interactions between metal compounds and vital proteins or biological targets. ${ }^{14,15}$ 
Herein, in a critical account, we briefly discuss and summarize some results from our laboratory on the antitumor properties of oxindolimine-copper(II) complexes (see Figure 1) that have benefited from a theoretical-experimental approach. All the metal complexes discussed here were synthesized in previous studies, ${ }^{16,17}$ with ligands prepared from appropriate carbonyl and amine precursors, and afterwards metalated based on procedures outlined formerly. ${ }^{18}$ Investigations of their antiproliferative activity toward HeLa cells and interactions with crucial biomolecules have been published elsewhere. ${ }^{19}$ Geometry optimizations, harmonic frequencies, and $\mathrm{Cu}$-L bonding analysis in different imine-copper complexes had been performed by density functional theory (DFT) by Caramori et al., ${ }^{20}$ using the exchange functional of Becke ${ }^{21}$ and the correlation functional of Perdew ${ }^{22}$ (PB86) as implemented in the Gaussian03 package. ${ }^{23}$

The strategy of uncovering the most important structural and spectroscopic characteristics of such oxindolimine-copper complexes by combining DFT studies and experimental EPR data has allowed further rationalization of their antiproliferative activities against tumor cells.

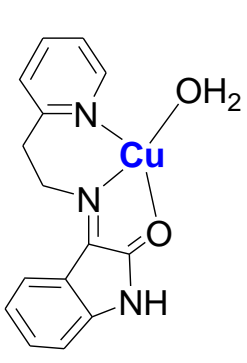

$\left[\mathrm{Cu}\right.$ (isaepy) $\left.\mathrm{H}_{2} \mathrm{O}\right]\left(\mathrm{ClO}_{4}\right)_{2}$

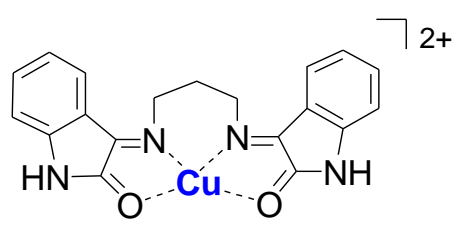

$[\mathrm{Cu}($ isapn $)]\left(\mathrm{ClO}_{4}\right)_{2}$

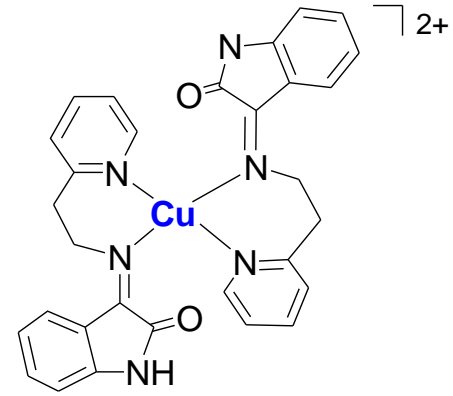

$\left[\mathrm{Cu}(\text { isaepy })_{2}\right]\left(\mathrm{ClO}_{4}\right)_{2}$

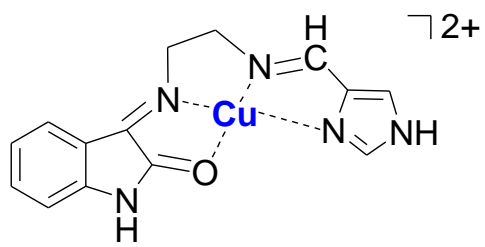

$[\mathrm{Cu}($ isaenim $)]\left(\mathrm{ClO}_{4}\right)_{2}$

Figure 1. Structures of the copper(II) complexes discussed here.

\section{DFT methods as a theoretical support for EPR spectroscopy}

As a case study for the utility of DFT simulations for the combined interpretation of EPR-based structural data with biologically relevant properties of copper(II) compounds, we will use a series of anticancer copper(II) compounds bearing imine ligands. Figure 2 shows the DFT-optimized structures evaluated in previous investigations. ${ }^{20}$

Two functionals, namely BPW91-35 and BPW91-60, were evaluated to understand the influence of spin density and EPR parameters on the combination of exact exchange in hybrid functionals, as previously studied by Kaupp. ${ }^{24}$ BP86 was shown to produce underestimated $g / /$ values.

Spin density plays a crucial role on the accurate representation of the simulated EPR parameters. To estimate the dependence of the spin polarization and spin delocalization on the exact-exchange admixture, 
the Mulliken spin densities were evaluated at the BP86/ TZVP level, where the exact-exchange admixture is 0.00 , and at the BPW91-60/TZVP levels, with 0.60 exact-exchange admixture.
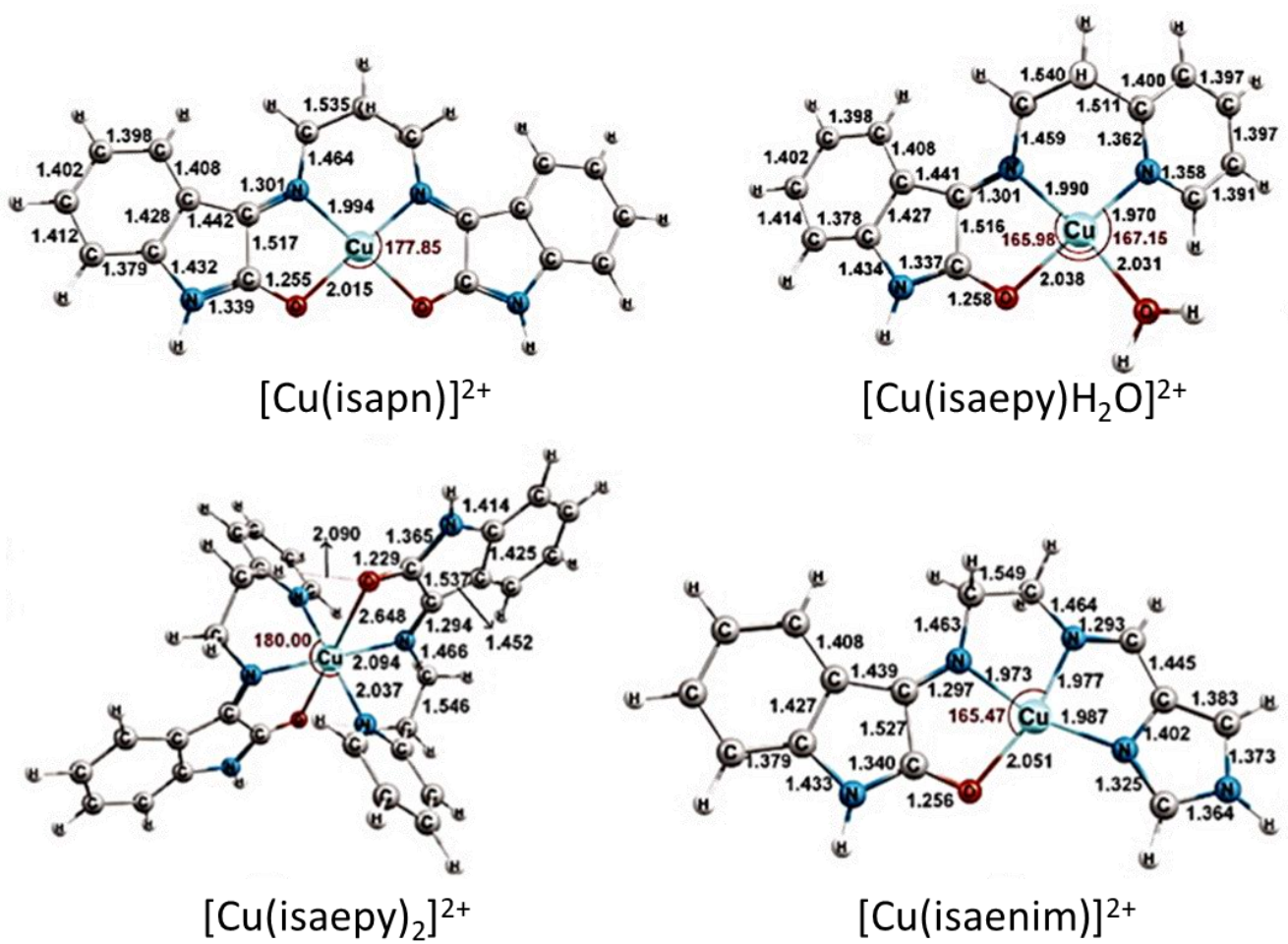

$[\mathrm{Cu}(\text { isaenim })]^{2+}$

Figure 2. DFT optimized structures of selected oxindolimine-Cu(II) compounds at the BP86/TZVP level of theory as implemented in Gaussian03. Adapted from Caramori et al. ${ }^{20}$

Spin-density distributions are shown in Figure 3 as isosurface plots. In column a, the isosurface plot obtained from the BPW91-60/TZVP combination, with a cutoff of 0.003 shows not only positive spin accumulation at the metal center and bonding atoms but also depletion in the spin density distribution along the $\mathrm{Cu}(\mathrm{II})-\mathrm{L}$ bonds, as expected for $a \mathrm{~d}^{9}$ configuration. Columns $\mathrm{b}$ and $\mathrm{c}$ compare the spin-density distributions calculated by using 60\% of Hartree-Fock exchange (BPW91-60) and the gradient-corrected level (BP86) in a cut-off of 0.0007 , respectively. The Mulliken spin densities reveal that at the gradient-corrected level (BP86), an extensive delocalization onto the Schiff-base nitrogen is observed. In this case, the spin density values on the metal range from 0.320 to 0.518 (a.u.), while for nitrogen atoms they range from 0.074 up to 0.216 (a.u.). At a 60\% HF Exchange level (BPW91-60), a more metal-centered spin distribution typical of a covalent $\mathrm{Cu}(\mathrm{II})-\mathrm{L}$ bonding is observed, which is more consistent with the relatively large experimental g anisotropy. In this case, the spin density on the metal center ranges from 0.658 up to 0.792 (a.u.). For [Cu(isapn)] ${ }^{2+}$, a slightly more delocalized spin density, independent of the functional, suggests an increase of the $\mathrm{Cu}(\mathrm{II})$-L bond covalency. 
$[\mathrm{Cu}(\text { isapn })]^{2+}$

$\left[\mathrm{Cu}\left(\text { isaepy) } \mathrm{H}_{2} \mathrm{O}\right]^{2+}\right.$

$\left[\mathrm{Cu}(\text { isaepy })_{2}\right]^{2+}$

$[\mathrm{Cu}(\text { isaenim })]^{2+}$
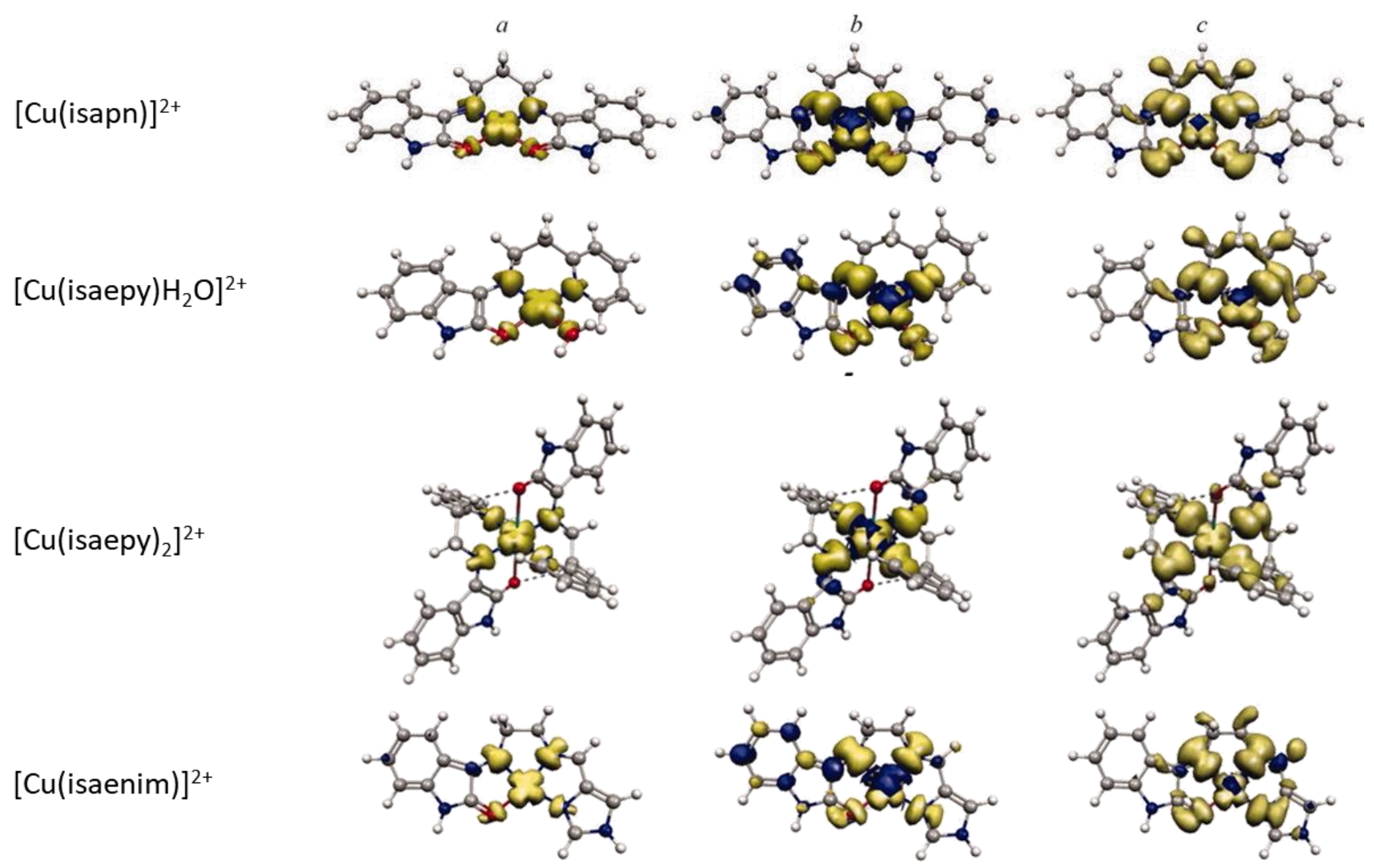

Figure 3. Isosurface plots of the Mulliken spin density obtained for the compounds using (a)cutoff of 0.003 at BPW91-60/TZVP, (b) 0.0007 at BPW91-60/TZVP and (c) 0.0007 at BP86/TZVP. Golden shapes correspond to positive spin densities. Adapted from Caramori et al. ${ }^{20}$

Finally, looking at the DFT-calculated g-tensor values: they were able to reproduce the same trend observed for experimental data, that is, $\mathrm{g}_{/ /}>\mathrm{g}_{\perp}>2.0023$. This can be assigned to the unpaired electron of $\mathrm{Cu}(\mathrm{II})$ in a $d_{x^{2}-y^{2}}$ orbital. It is important to notice that the gradient-corrected functional BP86 provided underestimated $g_{/ /}$and $g_{\perp}$ values in comparison with the available experimental data. This difference can be interpreted as a consequence of the covalent delocalization of $d_{x^{2}-y^{2}}$ orbitals onto the ligands, reducing their $\mathrm{d}$ character and consequently the orbital angular momentum, making the g values closer to 2.0023. However, the increase of HF exchange admixture, particularly when 35\% of HF exchange (BPW91-35) is employed, improves the overall agreement with the experimental data.

This approach demonstrates the utility and efficacy of combining DFT-obtained EPR parameters and spin density maps for interpreting the EPR data.

\section{EPR-based structural data and antiproliferative activities of copper(II) compounds}

The experimental EPR data for the oxindolimine-copper(II) compounds shown in Table 1 demonstrates that all compounds have an axial elongated geometry around the copper center, with some tetrahedral distortion in a tetragonal environment. They are corroborated by the corresponding DFT-obtained EPR parameters, that indicate a square planar geometry around the metal for all the compounds except for [Cu(isaepy $\left.)_{2}\right]$ which shows an octahedral geometry with a $z$ axis longer than the others. Differences between the DFT-obtained 
EPR parameters explored by Caramori et $a l^{20}$ and the experimental results may be related to the matrix influence on the g-tensors, which was not taken into account during the simulation.

Our group has also explored the antiproliferative activities of the same compounds towards neuroblastoma SH-SY $5 \mathrm{Y}^{16}$ and cervical HeLa ${ }^{17}$ cell lines. The results are summarized in Table 1 . In this study we can observe that the copper compound containing a single (asymmetric, tridentate) isaepy ligand is more active than the analog containing a single (symmetric, tetradentate) isapn complex. Very similar data were verified toward other tumor cell lines, as sarcoma uterine MES-SA cells, with $\mathrm{IC}_{50}$ of 15.3 and $92.2 \mu \mathrm{M}$, for $\left[\mathrm{Cu}(\right.$ isaepy $\left.) \mathrm{H}_{2} \mathrm{O}\right]$ and $\left[\mathrm{Cu}\left(\right.\right.$ isapn)], respectively. ${ }^{25}$ This behavior could be associated with the unpaired spin density, as observed by the isosurface plots shown in Figure 2. Compounds with the paramagnetic electron density less delocalized have a less covalent M-L bond. A delocalization of the unpaired electron between metal and the ligand is a strong evidence that this bond is more covalent, which has direct consequences on the complex stability in solution, polarity and other properties, as redox potential.

Table 1. Comparison of experimental and DFT-based EPR parameters obtained at the BPW91-35/TZVP level of theory, geometric parameters and antiproliferative activities of oxindolimine-copper(II) compounds, after $24 \mathrm{~h}$ incubation at $37^{\circ} \mathrm{C}$

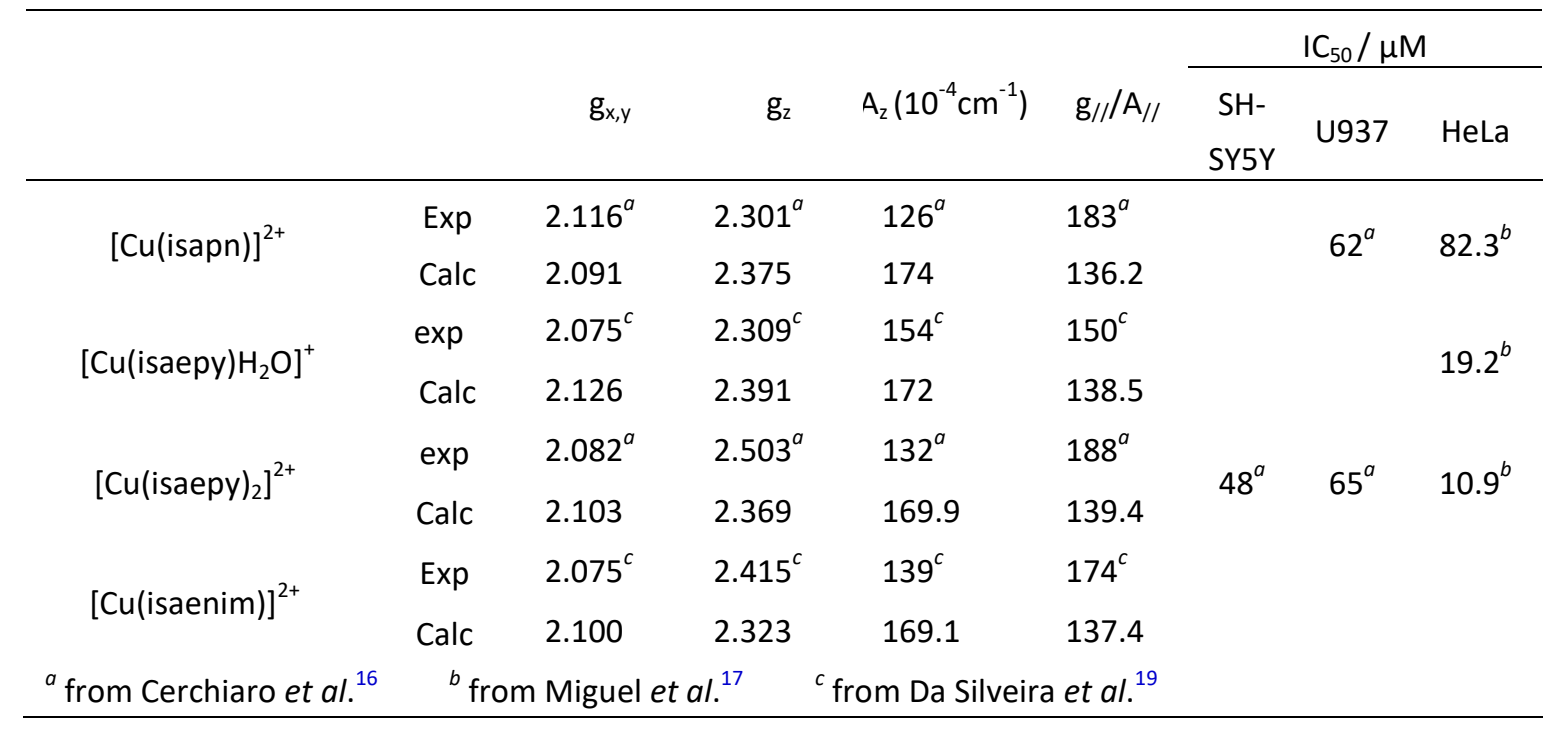

\section{Interactions of oxindolimine-copper(II) complexes with biomolecules}

Da Silveira et al. $^{19}$ evaluated the nuclease activity of compounds [Cu(isaepy) $\mathrm{H}_{2} \mathrm{O}$ ], [Cu(isaepy) $)_{2}$ and [Cu(isaenim)] towards a plasmid DNA by agarose gel electrophoresis studies. Resultant comparative results are shown in Figure 4. In terms of nuclease activity, the three compounds were shown to be similarly potent, acting mainly by an oxidative mechanism, where reactive oxygen species participate. However, the kinetics of reaction is different. As attested by Da Silveira et al., ${ }^{19}$ complexes [Cu(isaepy) $\mathrm{H}_{2} \mathrm{O}$ ] and [Cu(isaepy) ${ }_{2}$ ] are in equilibrium. DNA cleavage is observed as soon as after 15 minutes of incubation, and at concentrations as low as $1 \mu \mathrm{M}$. After $30 \mathrm{~min}$, plasmid samples treated with $25 \mu \mathrm{M}$ of each compound show evidence of a second cleavage that yields a linear fragment. In the Figure the formation of form III (Linear DNA) in each case is compared. This assay demonstrates that the antiproliferative activities observed for the compounds can be linked to intracellular DNA damage. Further, relating binding constants to plasmid DNA, in competitive assays 
with ethidium bromide inserted in the strands, are consistent with these data, since the determined values are in the range of 3 to $9 \times 10^{2} \mathrm{M}^{-1},{ }^{26}$ comparable to that of copper(II)-phenanthroline species, $\left[\mathrm{Cu}(\mathrm{o}-\mathrm{phen})_{2}\right]^{2+}$.

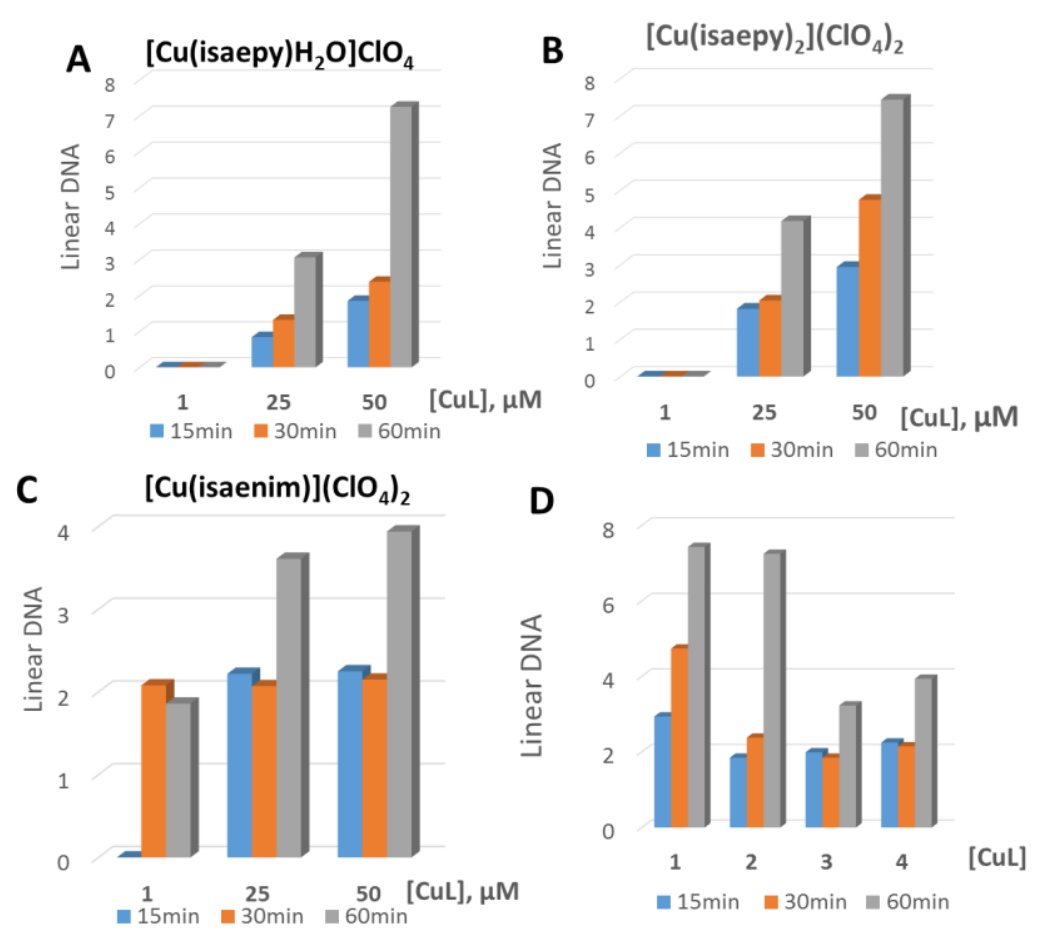

Figure 4. Double DNA cleavage by oxindolimine-copper(II) complexes A. $\left[\mathrm{Cu}\left(\right.\right.$ isaepy $\left.\left._{3} \mathrm{H}_{2} \mathrm{O}\right)\right] \mathrm{ClO}_{4}, \mathrm{~B}$. $\left[\mathrm{Cu}(\text { isaepy })_{2}\right]\left(\mathrm{ClO}_{4}\right)_{2}$ and $\mathrm{C}$. [ $\mathrm{Cu}($ isaenim) $]\left(\mathrm{ClO}_{4}\right)_{2}$ at different concentrations and incubation times. D. Relative amounts of formed linear DNA after treatment with the different complexes $(50 \mu \mathrm{M})$, following the code: 1 . $\left.[\mathrm{Cu} \text { (isaepy) })_{2}\right]\left(\mathrm{ClO}_{4}\right)_{2} ;$ 2. [Cu(isaepy) $\left.\mathrm{H}_{2} \mathrm{O}\right] \mathrm{ClO}_{4} ; 3$. [ $\mathrm{Cu}($ enim $\left.) \mathrm{H}_{2} \mathrm{O}\right]\left(\mathrm{ClO}_{4}\right)_{2}$; and 4. [Cu(isaenim)] $\left(\mathrm{ClO}_{4}\right)_{2}$. Adapted from Da Silveira et al. ${ }^{19}$

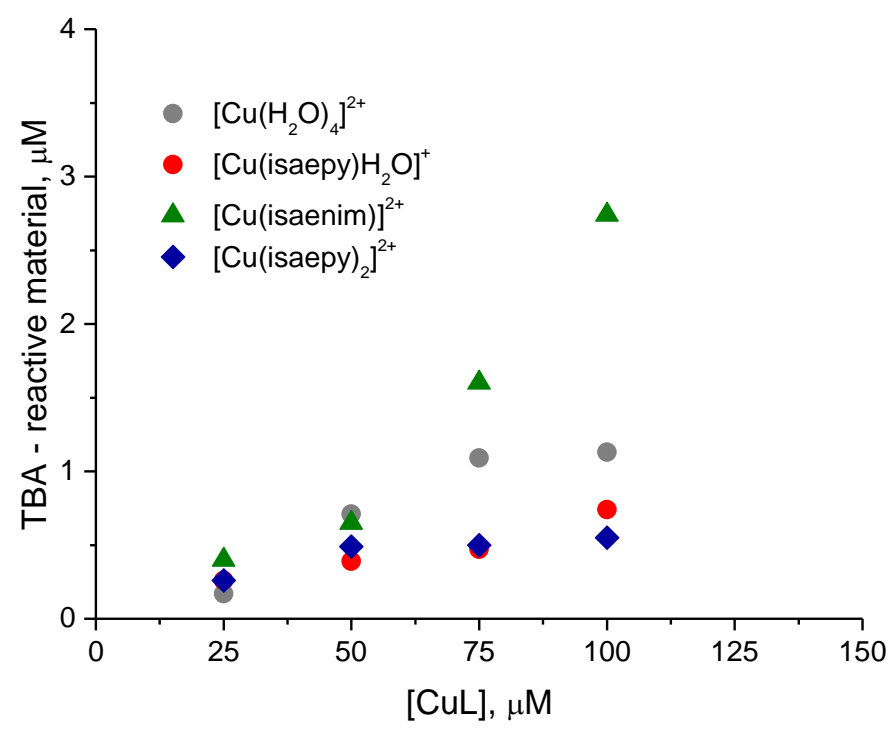

Figure 5. Oxidation of 2-deoxy-D-ribose $(2.5 \mathrm{mM})$ catalyzed by different oxindolimine-copper(II) complexes. Incubation for $1 \mathrm{~h}$, at $37^{\circ} \mathrm{C}$ and $\mathrm{pH} 7.4$, in the presence of $\mathrm{H}_{2} \mathrm{O}_{2}(1.0 \mathrm{mM})$. Adapted from Da Silveira et al. ${ }^{19}$ 
The same series of compounds was also studied in terms of catalytic oxidative damage towards 2-deoxy$D$-ribose. ${ }^{19}$ The copper(II) compounds were evaluated under different concentrations against a fixed amount of the ribose and the reaction monitored by the TBARS (2-thiobarbituric acid reactive species) method. Figure 5 shows that $[\mathrm{Cu}($ isaenim)] has the most pronounced oxidative effect towards the substrate, while $\left[\mathrm{Cu}(\right.$ isaepy $\left.) \mathrm{H}_{2} \mathrm{O}\right]$ and $\left[\mathrm{Cu}(\text { isaepy })_{2}\right]$ had lower activities, compared to the control $\left[\mathrm{Cu}\left(\mathrm{H}_{2} \mathrm{O}\right)_{4}\right]^{2+}$.

Comparing nuclease activity with the oxidative properties towards 2-deoxy- $D$-ribose, we can observe that all three compounds are able to interact with DNA to some extent and efficiently promote cleavages. On the other hand, among the three compounds evaluated in these studies, [Cu(isaenim) $]^{2+}$ was the only potent oxidant of 2-dexy-D-ribose, indicating a possible targeting on the sugar moiety of the nucleotide. This compound also exhibited a substantially delocalized spin density, as demonstrated by the isosurface plots in Figure 3. A correlation of oxidative damage caused with spin density delocalization once again arises from these studies.

\section{Conclusions}

Correlating the experimental data on the reactivity of these copper(II) complexes toward target biomolecules and tumor cells with DFT-obtained electron density distribution and optimized geometries, along with EPR parameters, we observe interesting trends. Our data indicated that the more asymmetric ligands lead to a higher delocalization and stabilization of the corresponding complexes, improving their reactivity. That explains why $[\mathrm{Cu}($ isaepy)] or $[\mathrm{Cu}($ isaenim)] are more reactive than $[\mathrm{Cu}(\mathrm{isapn})]$ in the biological studies, comprehending antiproliferative assays, 2-deoxy-D-ribose oxidation as well as DNA binding and cleavage tests. This approach can inspire future studies in bioinorganic and medicinal fields, based mainly on asymmetric compounds.

\section{Acknowledgements}

The authors are grateful to São Paulo State Research Foundation (FAPESP) for financial support (grants no. 2011/50318-1, 2018/21537-6) and CEPID Redoxoma Network (FAPESP Process no. 2013/07937-8).

\section{References}

1. Sciortino, G.; Garribba, E.; Maréchal, J.-D. Inorg. Chem. 2019, 58, 294.

https://doi.org/10.1021/acs.inorgchem.8b02374

2. Sciortino, G.; Garribba, E.; Rodríguez-Guerra Pedregal, J.; Maréchal, J.-D. ACS Omega 2019, 4, 3726. https://doi.org/10.1021/acsomega.8b03457

3. Abbehausen, C.; de Paiva, R. E. F.; Bjornsson, R.; Gomes, S. Q.; Du, Z.; Corbi, P. P.; Lima, F. A.; Farrell, N. Inorg. Chem. 2018, 57, 218.

https://doi.org/10.1021/acs.inorgchem.7b02406

4. Spatzal, T.; Aksoyoglu, M.; Zhang, L.; Andrade, S. L. A.; Schleicher, E.; Weber, S.; Rees, D. C.; Einsle, O. Science (80-.). 2011, 334, 940. https://doi.org/10.1126/science.1214025 
5. Ferreira, R. A. A.; Pauli, I.; Sampaio, T. S.; de Souza, M. L.; Ferreira, L. L. G.; Magalhães, L. G.; Rezende, C. de O.; Ferreira, R. S.; Krogh, R.; Dias, L. C.; Andricopulo, A. D. ; Front. Chem. 2019, 7, Article 798. https://doi.org/10.3389/fchem.2019.00798

6. Molphy, Z.; Montagner, D.; Bhat, S. S.; Slator, C.; Long, C.; Erxleben, A.; Kellett, A. Nucleic Acids Res. 2018, $46,9918$.

https://doi.org/10.1093/nar/gky806.

7. Molphy, Z.; Prisecaru, A.; Slator, C.; Barron, N.; McCann, M.; Colleran, J.; Chandran, D.; Gathergood, N.; Kellett, A. Inorg. Chem. 2014, 53, 5392.

https://doi.org/10.1021/ic500914j

8. Nunes, J. H. B.; de Paiva, R. E. F.; Cuin, A.; da Costa Ferreira, A. M.; Lustri, W. R.; Corbi, P. P. ; J. Mol. Struct. 2016, 1112, 14. https://doi.org/10.1016/j.molstruc.2016.02.006

9. Nakahata, D. H.; de Paiva, R. E. F.; Lustri, W. R.; Ribeiro, C. M.; Pavan, F. R.; da Silva, G. G.; Ruiz, A. L. T. G.; de Carvalho, J. E.; Corbi, P. P. J. Inorg. Biochem. 2018, 187, 85.

https://doi.org/10.1016/i.jinorgbio.2018.07.011

10. Castelli, S.; Gonçalves, M.B.; Katkar, P.; Stuchi, G.C.; Couto, R.A.A.; Petrilli, H.M.; Da Costa Ferreira, A.M. J. Inorg. Biochem. 2018, 186, 85.

https://doi.org/10.1016/i.jinorgbio.2018.05.012.

11. Stoll, S.; Schweiger, A. J. Magn. Reson. 2006, 178, 42.

https://doi.org/10.1016/j.jmr.2005.08.013

12. de Almeida, K. J.; Rinkevicius, Z.; Hugosson, H. W.; Ferreira, A. C.; Ågren, H. Chem. Phys. 2007, $332,176$. https://doi.org/10.1016/i.chemphys.2006.11.015

13. Schöneboom, J. C.; Neese, F.; Thiel, W. J. Am. Chem. Soc. 2005, 127, 5840. https://doi.org/10.1021/ja0424732

14. Da Silveira, V.C.; Abbott, M.P.; Cavicchioli, M.; Gonçalves, M.B.; Petrilli, H. M.; Rezende, L.; do Amaral, A.T., Fonseca, D.E.P.; Caramori, G. F. ; Da Costa Ferreira, A.M. Dalton Trans. 2013, 42, 6386-6396. https://doi.org/10.1039/C3DT00108C

15. Mori, M.; Dietrich, U.; Manetti, F.; Botta, M. J. Chem. Inf. Model. 2010, 50, 638. https://doi.org/10.1021/ci100070m

16. Cerchiaro, G.; Aquilano, K.; Filomeni, G.; Rotilio, G.; Ciriolo, M. R.; Da Costa Ferreira, A. M. J. Inorg. Biochem. 2005, 99, 1433. https://doi.org/10.1016/j.jinorgbio.2005.03.013

17. Miguel, R. B.; Petersen, P. A. D.; Gonzales-Zubiate, F. A.; Oliveira, C. C.; Kumar, N.; do Nascimento, R. R.; Petrilli, H. M.; Da Costa Ferreira, A. M. J. Biol. Inorg. Chem. 2015, 20, 1205. https://doi.org/10.1007/s00775-015-1300-4

18. Costa Ferreira, A.M.G.; Krumholz, P.; Riveros, J.M. Dalton Trans. 1977, 896. https://doi.org/10.1039/DT9770000896

19. Da Silveira, V. C.; Luz, J. S.; Oliveira, C. C.; Graziani, I.; Ciriolo, M. R.; Ferreira, A. M. D. C. J. Inorg. Biochem. 2008, 102, 1090. https://doi.org/10.1016/i.jinorgbio.2007.12.033

20. Caramori, G. F.; Parreira, R. L. T.; Da Costa Ferreira, A. M. Int. J. Quantum Chem. 2012, 112, 625. https://doi.org/10.1002/qua.23030

21. Becke, A. D. Phys. Rev. A 1988, 38, 3098. https://doi.org/10.1103/PhysRevA.38.3098 . 
22. Perdew, J. P. Phys. Rev. B 1986, 33, 8822.

https://doi.org/10.1103/PhysRevB.34.7406.

23. Frisch, M. J.; Trucks, G. W.; Schlegel, H. B.; Scuseria, G. E.; Robb, M. A.; Cheeseman, J. R.; Montgomery, J. A., Jr.; Vreven, T.; Kudin, K. N.; Burant, J. C.; Millam, J. M.; Iyengar, S. S.; Tomasi, J.; Barone, V.; Mennucci, B.; Cossi, M.; Scalmani, G.; Rega, N.; Petersson, G. A.; Nakatsuji, H.; Hada, M.; Ehara, M.;

Toyota, K.; Fukuda, R.; Hasegawa, J.; Ishida, M.; Nakajima, T.; Honda, Y.; Kitao, O.; Nakai, H.; Klene, M.; Li, X.; Knox, J. E.; Hratchian, H. P.; Cross, J. B.; Adamo, C.; Jaramillo, J.; Gomperts, R.; Stratmann, R. E.; Yazyev, O.; Austin, A. J.; Cammi, R.; Pomelli, C.; Ochterski, J. W.; Ayala, P. Y.; Morokuma, K.; Voth, G. A.; Salvador, P.; Dannenberg, J. J.; Zakrzewski, V. G.; Dapprich, S.; Daniels, A. D.; Strain, M. C.; Farkas, O.; Malick, D. K.; Rabuck, A. D.; Raghavachari, K.; Foresman, J. B.; Ortiz, J. V.; Cui, Q.; Baboul, A. G.; Clifford, S.; Cioslowski, J.; Stefanov, B. B.; Liu, G.; Liashenko, A.; Piskorz, P.; Komaromi, I.; Martin, R. L.; Fox, D. J.; Keith, T.; Al-Laham, M. A.; Peng, C. Y.; Nanayakkara, A.; Challacombe, M.; Gill, P. M. W.; Johnson, B.; Chen, W.; Wong, M. W.; Gonzalez, C.; Pople, J. A. Gaussian 03, Revision A.1, Gaussian, Inc.: Pittsburgh, PA, 2003.

24. Remenyi, C.; Munzarová, M. L.; Kaupp, M. J. Phys. Chem. B 2005, 109, 4227-4233. https://doi.org/10.1021/ip045148+

25. Miguel, R. B., Ph.D. Thesis, Intracellular targets and mechanism of action of copper(II) and zinc(II) oxindolimine complexes with antitumor activity, 2018, University of São Paulo, SP, Brazil.

26. Da Silveira, V. C.; Henri Benezra; Luz, J. S.; Georg, R.C.; Oliveira, C. C.; Da Costa Ferreira, A. M. J. Inorg. Biochem. 2011, 105, 1692.

https://doi.org/10.1016/j.jinorgbio.2011.09.016

\section{Authors' Biographies}

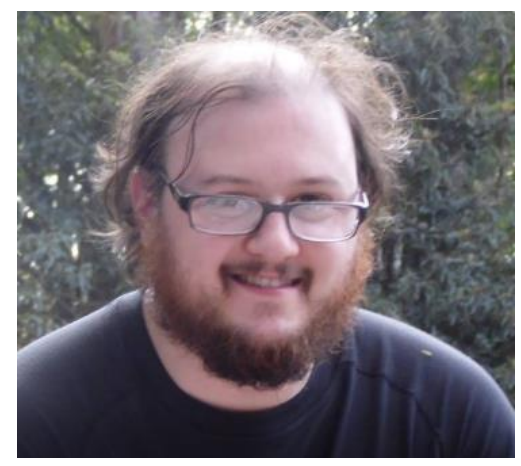

Rodrigo Boni Fazzi was Born in São Paulo, Brazil in 1988. He received his BSc degree from Universidade de São Paulo (USP) in 2015. In the same year, joined at Ana Ferreira's lab, to work with EPR spectroscopy and polynuclear complex syntheses and characterization. He is presently finishing his Ph.D. In Chemistry. 


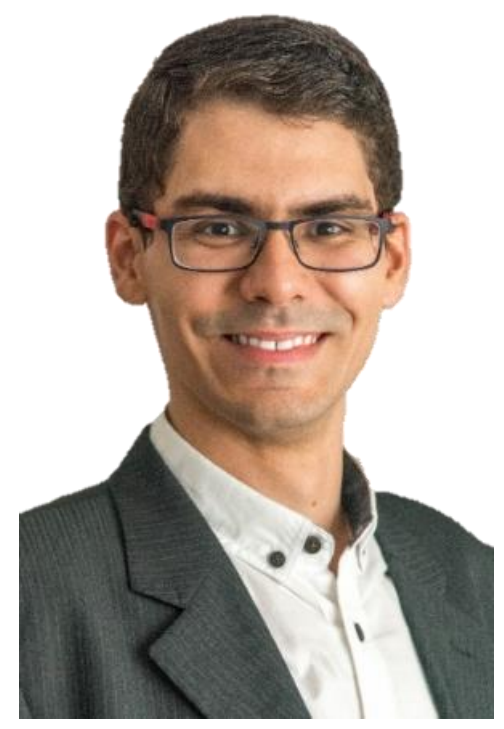

Raphael Enoque Ferraz de Paiva was born in Brazil in 1989. He obtained a Master's degree in 2014 and PhD degree 2017 at University of Campinas (Brazil) under the supervision of Professor Pedro P. Corbi, with a focus on the development of metallopharmaceutical compounds. During his PhD, he spent one year as an exchange student at Virginia Commonwealth University (USA) working with Professor Nicholas P. Farrell. After his PhD, he worked as a visiting research fellow at Griffith University's Institute for Glycomics (Gold Coast, Australia) under the supervision of Sue Berners-Price, where he explored cobalt compounds under the light of the metalloglycomics field. He is currently working as a post-doctoral fellow at University of São Paulo (USP) with Ana Maria da Costa Ferreira.

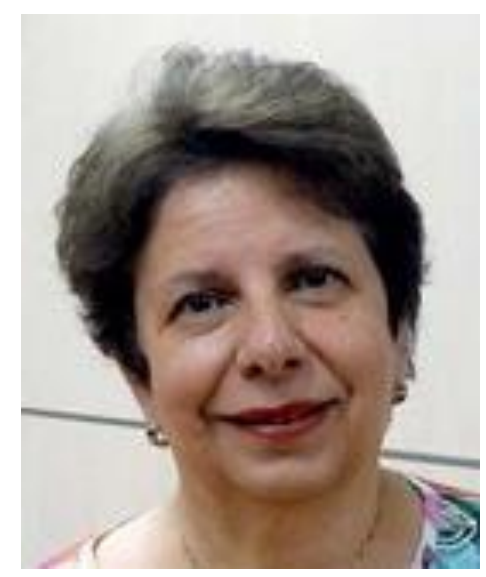

Ana Maria da Costa Ferreira was born in Brazil in 1949. She received her PhD. degree in Chemistry from University of São Paulo (USP), São Paulo, Brazil, in 1976, under the supervision of Professor José Manuel Riveros and Professor Pawel Krumholz. She is a full professor of Inorganic Chemistry at USP, responsible for the Laboratory on Bioinorganic, Catalysis and Pharmacology. Her main research interests include the reactivity of metal ions in biological systems, oxidative processes, and the development of antitumor and antiparasite metallodrugs based on essential metals. 